\title{
Anthropogenic induced changes in nesting densities of the dune-specialised digger wasp Bembix rostrata (Hymenoptera: Sphecidae)
}

\author{
DRIES BONTE \\ Department of Biology, Research Unit Terrestrial Ecology, Ghent University, K.L. Ledeganckstraat 35, B-9000 Ghent, Belgium; \\ e-mail: Dries.Bonte@Ugent.be
}

Key words. Hymenoptera, Sphecidae, Bembix rostrata, disturbance, population density, recreation, trampling

\begin{abstract}
Data on nesting densities of Bembix rostrata, a digger wasp inhabiting dynamic coastal dunes, were used to document the detrimental effects of trampling by cattle and vacationers. Both types of disturbance resulted in similar sand displacement and prey availability. Nesting densities of Europe's largest digger wasp declined dramatically with increasing trampling, probably below the critical population size. Hence, additional human disturbance, although resulting in similar environmental conditions compared to natural disturbance, significantly affected local population sizes. As a result, anthropogenic has to be avoided disturbance in order to restore or conserve natural dynamics and efforts to restore natural dynamics in a more natural way should be promoted. Although this is here only documented for one, large specialised invertebrate, the application of traditional management techniques, such as grazing by large herbivores, within newly evolved landscapes may introduce new pressures that affect pre-adapted species to natural disturbances negatively within short time spans.
\end{abstract}

\section{INTRODUCTION}

Disturbance plays an essential role in maintaining biotic diversity (White \& Jentsch, 2001). Although the development of generalisations is challenging, consideration of the diverse effects of similar disturbances is required. Species adapted to a particular ecosystem, and thus their degree of plasticity towards disturbance of that ecosystem, illustrate past selection pressures (Wiegand et al., 1997). Yet, adaptive changes in life history traits may be insufficient to overcome recent, anthropogenicinduced disturbances, even if such disturbance results in a similar habitat structure. Within the framework of conservation, the tolerance of species towards apparently similar disturbances are often generalised, without more profound studies on the scales and processes underlying the disturbances in question (Hobbs \& Yates, 2003; Denny et al., 2004). For coastal dunes in particular, human disturbance is often accepted because of the tolerance of species towards natural disturbance, i.e. aeolic dynamics (displacement of sand by wind).

In dune ecosystems, aeolic dynamics form an essential part of the geomorphological processes (Kalivodová et al., 2002; Provoost, 2004), which are typified by an absence of soil development and extreme microclimatic conditions. This habitat harbours a highly specific biodiversity well-adapted to frequent sand overblowing events (Bonte et al., 2004; Provoost \& Bonte, 2004), but vulnerable to changes in habitat quality due to diminishing sand dynamics (e.g. Bach, 2001; Bonte et al., 2002, 2004; Kowalchuk et al., 2002; Snyder \& Boss, 2002; Franks \& Peterson, 2003; Jun et al., 2004). However, the responses of species towards anthropogenic cumulative disturbances within the ecosystem are poorly documented. Here, I document how nesting densities of Europe's largest xerothermic digger wasp, Bembix rostrata (Linnaeus, 1758), in a habitat with natural disturbance is affected by additional anthropogenic disturbances, i.e. cattle grazing and human recreation, both of which do not dramatically alter the habitat structure.

\section{MATERIAL AND METHODS}

\section{Study species}

Bembix rostrata is a specialised, gregariously nesting digger wasp found in sandy regions of Europe (Larsson, 1986), the wasp nesting in sand dunes with low vegetation cover (Klein 1996; Peeters et al., 2004). It is the largest European species of digger wasps and is threatened in many countries (Zegers, 2001; Van der Meer, 2002; Provoost \& Bonte, 2004). Although the nesting season extends from July-October, larvae are only present at the end of the summer. According to Nielsen (1945) and Peeters et al. (2004), females construct one nesting burrow at a time. The burrow contains one larva which is provisioned with flies, mainly hoverflies (Syrphidae). Adult wasps feed on nectar. The nesting cycle includes nest construction, oviposition, food provisioning and, finally, nest closure. In order to orientate to their nest burrow, B. rostrata exhibits a well developed homing behaviour (Schöne \& Tengö, 1981; Schöne et al., 1993; Tengö et al., 1996), which makes use of landmarks and sun compassorientation.

Study area, determination of environmental parameters and nest aggregation size

Nest aggregation densities were recorded along 65 transects in the dune reserve and surrounding dunes of the "WesthoekPerroquet" in De Panne-Bray Dunes (Belgium and France). The entire dune area extends over 650 ha and is dominated by shrub (Hippophae rhamnoides) vegetation. Within this area, grey dunes (moss dominated xerotherm vegetation belonging to the Tortula-Koelerion vegetation type, showing grey colouration during summer drought - see Provoost et al., 2004) comprise the optimal habitat for B. rostrata (Provoost \& Bonte, 2004). This habitat type is continuously distributed along a mobile wandering dune. Fragments are (i) open for public recreation, (ii) closed to the public or (iii) inaccessible to the public, but grazed by cattle and horses (see inlay Fig. 1). Although detailed data on anthropogenic disturbance are lacking, public recreation mainly occurs during summer season (nesting season of $B$. rostrata) and easily exceeds $300 \mathrm{~h}$ of recreation disturbance during the months July-August on all accessible grey dunes (Tourist 
Office De Panne, pers. comm.). In contrast, cattle spend yearly only $7-9 \%$ of time on open vegetation and grey dunes resulting in a mean annual disturbance of less than $0.2 \mathrm{~h} /$ year $/ \mathrm{m}^{2}$ (Lamoot et al., 2005). This grazing mainly occurs during winter and spring (Lamoot et al., 2005). Sand compaction is, in both cases, negligible due to aeolic dynamics. As a result, disturbance pressure due to recreation is considerably more intensive than cattle grazing.

In the grey dunes fragments I recorded $B$. rostrata nests along $30 \mathrm{~m}$ transect within a distance of $2 \mathrm{~m}\left(120 \mathrm{~m}^{2}\right)$ on three consecutive days during the first week of September 2004. This period, at the end of the tourist season, was chosen because it enabled us to investigate patterns of nesting densities after the disturbance, so avoiding the recording of temporary nesting sites that would have been abandoned during the disturbance season. Furthermore, only female wasps enter nests during this period because males have disappeared from the population. In this way, over-estimation of population size by counting male sleeping burrows was avoided. 23 transects were located in the zone inaccessible for cattle and recreation, 20 transects in the zone with public recreation and 22 in the zone under the influence of grazing livestock. Nests were marked with labelled sticks to avoid double counting. Because females are active mainly during sunny periods with high temperatures, observations were made between $10 \mathrm{~h} 30^{\prime}$ and $16 \mathrm{~h} 00^{\prime}$. Proportional differences in the vegetation structure in five $2 * 2 \mathrm{~m}^{2}$ quadrants randomly located along the transect were also estimated (coverage of mosses, bare sand and the amount of trampled soil). Trampled vegetation is recognised by the mechanical destruction of the moss-layer. Along the transects, we counted the number of flowering ragwort (Senecio jacobaea), the main nectariferous flower (Klein, 1996; Peeters et al., 2004), and the number of potential prey for the wasp larva (Syrphidae; mainly Episyrphus balteatus) on the flowers. Five sand deposition traps along each transect (jars of diameter $9 \mathrm{~cm}$ ) recorded the net sand replacement (aeolic dynamics, $\mathrm{cm}$ ) in the area from the second half of August until the first half of September.

\section{Statistical analyses}

Data on nest, nectar plant and potential prey counts, aeolic dynamics and vegetation coverage were tested between the three disturbance regimes by generalized linear models with log link function and Poisson error structure. Data from sand deposition traps and vegetation quadrants were included as random factors, nested within transect. Calculations were done with the SAS procedure Glimmix (SAS statistical package version 9.1). An $\alpha$-value of 0.05 was used for hypothesis acceptation.

\section{RESULTS}

Vegetation structure, aeolic dynamics and resource availability (Fig. 1)

Coverage of moss (an inverse measure of coverage of bare sand; $\left.F_{2,262}=0.37 ; \mathrm{P}>0.05\right)$ and net sand displacement $\left(\mathrm{F}_{2,187}=\right.$ 2.12; $\mathrm{P}>0.05)$ did not differ between disturbance regimes. The coverage of the trampled area, however, differed in function of disturbance $\left(\mathrm{F}_{2,262}=18.12 ; \mathrm{P}<0.001\right)$ and was significantly lower in sites without recreational or grazing influence (Bonferroni corrected pairwise comparison, $\mathrm{P}<0.016$ ). The density of nectar plants showed no differences between disturbance regimes $\left(\mathrm{F}_{2,62}=0.68 ; \mathrm{P}>0.05\right)$. Syrphid densities depended on nectar flower density $\left(\mathrm{F}_{1,59}=30.60 ; \mathrm{P}<0.0001\right)$. No differences in function of disturbance $\left(\mathrm{F}_{2,59}=0.37 ; \mathrm{P}>0.05\right)$ were recorded and interaction with nectar plant density $\left(\mathrm{F}_{2,59}=0.15 ; \mathrm{P}>0.05\right)$ was not significant.

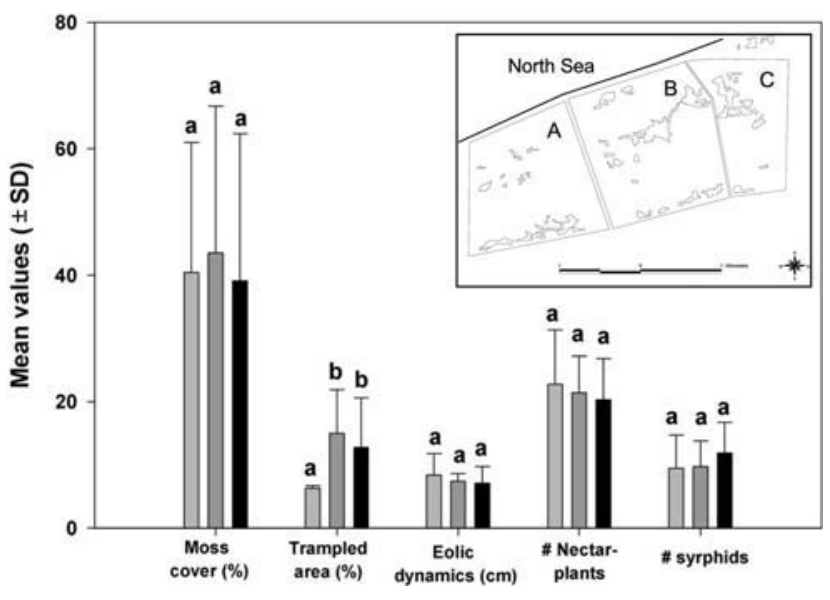

Fig. 1. Variation in habitat structure and resource availability along grey dune transects with natural (eolic) disturbance, recreation and trampling disturbance by introduced large grazers. Different letter notations indicate significant differences between disturbance regimes (light grey: no grazing or recreation; dark grey: recreation; black: grazing). Inlay: location of grey dune fragments within the study area with zonation of different anthropogenic disturbances (A: recreation; B: grazing; C: no grazing or recreation).

\section{Nesting densities (Fig. 2)}

Nesting densities reached $37 \pm 21.76$ in transects without anthropogenic disturbance, $0.8 \pm 1.57$ in the recreational zone and $0.5 \pm 1.18$ along transects with livestock grazing and show a significant difference $\left(\mathrm{F}_{2,62}=33.57 ; \mathrm{P}<0.001\right)$. Bonferroni corrected pairwise comparison revealed no differences in nesting densities between transects affected by recreational and grazing disturbance $\left(\mathrm{F}_{1,40}=0.08 ; \mathrm{P}>0.05\right)$.

\section{DISCUSSION}

As shown by Schöne \& Tengö (1981), Larsson (1986) and Peeters et al. (2004), B. rostrata requires habitat with considerable bare sand for gregarious nesting. In dunes, these conditions occur naturally by sand displacement caused by strong winds (Provoost, 2004). In other regions without these natural dynamics, the species also occupies habitats that are influenced by anthropogenic disturbance, such as road paths (Schöne \&

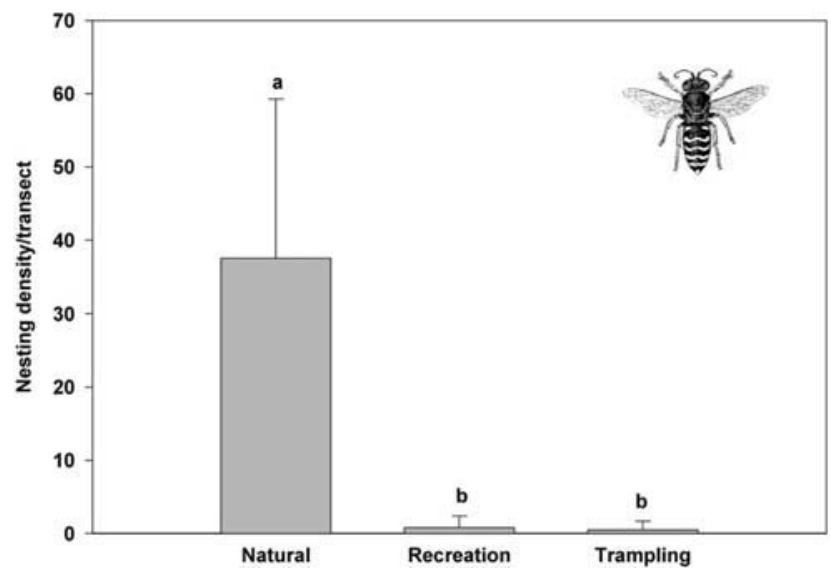

Fig. 2. Bembix rostrata nesting densities along grey dune transects with natural (aeolic) dynamics, recreation and trampling disturbance. Different letter notations indicate significant differences between disturbance regimes. 
Tengö, 1981). As for other (related) gregarious species (e.g. Bembicinus hungaricus; Kalivodova et al., 2002; Ammophila pubescens, Philanthus triangulum; Peeters et al., 2004), disturbance is necessary to retain the ephemeral soil conditions in which gregarious nesting is possible, but tolerance to the magnitude of disturbance seems species-specific and related to life history characteristics (e.g. duration of larval development, depth of nesting, degree of mother care; Peeters et al., 2004). As demonstrated here, additional disturbance affects nesting performance in B. rostrata. This possibly also holds for other largebodied insects, given their extreme vulnerability for anthropogenic disturbance in fragmented habitats (Boughton \& Malvadkar, 2002; Henle et al., 2004; Magura et al., 2004). In our study area, cattle trampling occurs throughout the year (although introduced grazers do not show a preference for this habitat: Lamoot et al., 2005), while recreational pressure peaks during summer. However, these anthropogenic-induced disturbances do not, with the exception of the magnitude of trampled vegetation, result in an apparent change of the habitat structure compared to natural dynamics, but effects on $B$. rostrata nesting densities are significant. Although grazers frequent grey dune habitats less than vacationers, similar declines in nesting densities were observed. In contrast to aeolic dynamics, occurring during the winter and autumn-season in which $B$. rostrata develops below the surface (Nielsen, 1945), disturbances from recreation occur during the summer season when females provision their larva continuously with prey. It is thus reasonable to suggest that disturbance during this period interacts with the species' nourishment behaviour (including homing; Schöne et al., 1993) in a direct way or by destroying unfinished nests, so preventing females from retrieving larvae. Trampling by cattle, however, mainly occurs during winter and spring (Lamoot et al., 2005) so declines in nest densities cannot be solely attributed to activities during the reproductive season. Possibly, trampling also affects larval survival directly during winter and spring, periods with lower additional disturbance. In general, nesting densities with additional anthropogenic disturbance are extremely low (Larsson, 1986), perhaps below lower critical population sizes and populations are possibly only maintained by rescue-effects from neighbouring populations with nondisturbed conditions. Furthermore, even if populations persist under trampling disturbances, smaller nesting aggregations are more strongly affected by parasites (Metopia leucocephala, Sarcophagidae, Diptera) and predators (see Larsson, 1986). Therefore, it can be concluded that population sizes are declining rather due to the deterioration of nest site quality by changes in the structure of the soil surface (Gess \& Gess, 1993), than by the decrease in availability of resources (Kearns \& Inouye, 1997; Potts et al., 2003; Steffan-Dewenter \& Leschke, 2003).

$B$. rostrata, although a species, (pre-)adapted to dynamic dune systems, is not able to cope with additional human disturbance pressures. Effects of disturbance can not be generalised (e.g. Hobbs \& Yates, 2003) and distinctions need to be made between the anthropogenic and natural disturbance mechanisms which both, at first sight, create similar habitat conditions. Dune ecosystem restoration by introducing cattle should also not be generally and unquestionably accepted as the ultimate conservation tool. Although grazers prefer more nutritious vegetation (Lamoot et al., 2005), the current shrub-encroached landscape (Provoost, 2004) forces them to use scarce vegetation as corridors between optimal habitats (Lamoot et al., 2005). Although I only focused here on one (large) species, the application of traditional management techniques within newly evolved landscapes may open Pandora's boxes because they introduce new pressures to which assumed (pre-)adapted species may be negatively affected within short time spans. This case study is illus- trative and opens the discussion and the need for more research on how species cope with anthropogenic disturbances induced by current land management practises.

ACKNOWLEDGEMENT. I would like to thank J.-L. Herrier for research permission in the nature reserve "Westhoek". The author is a postdoctoral fellow at the FWO-Flanders.

\section{REFERENCES}

BACH C.E. 2001: Long-term effects of insect herbivory and sand accretion on plant succession on sand dunes. Ecology 82: 1401-1416.

Bonte D., Baert L. \& Maelfait J.-P. 2002: Spider assemblage structure and stability in a heterogeneous coastal dune system (Belgium). J. Arachnol. 30: 331-343.

Bonte D., Criel P., Vanhoutte L., Van Thournout I. \& MaelFAIT J.-P. 2004: The importance of habitat productivity, stability and heterogeneity for spider species richness in coastal grey dunes along the North Sea and its implications for conservation. Biodiv. Conserv. 13: 2119-2134.

Boughton D. \& MalvadKar U. 2002: Extinction risk in successional landscapes subject to catastrophic disturbances. Conserv. Ecol. 6(2): 2. [online] URL: http://www.consecol.org/ vol6/iss $2 /$ art2/

Denny M.W., Helmuth B., Leonard G.H., Harley C.D.G., Hunt L.J.H. \& Nelson E.K. 2004: Quantifying scale in ecology: Lessons from a wave-swept shore. Ecol. Monogr. 74: 513-532

Franks S.J. \& Peterson C.J. 2003: Burial disturbance leads to facilitation among coastal dune plants. Plant Ecol. 168: 13-21.

Gess F.W. \& Gess S.K. 1993: Effects of increased land utilisation on species representation and diversity of aculeate wasps and bees in the semi-arid areas of Southern Africa. In Lasalle J. \& Gauld I.D. (eds): Hymenoptera and Biodiversity. CAB International, Wallingford, UK, pp. 83-113.

Henle K., Davies K.F., Kleyer M., Margules C., Settele J. 2004: Predictors of species sensitivity to fragmentation. Biodiv. Conserv. 13: 207-251 .

Hobbs R.J. \& Yates C.J. 2003: Impacts of ecosystem fragmentation on plant populations: generalising the idiosyncratic. Austr. J. Bot. 51: 471-88.

Jun R., Clement R.B. \& Roze F. 2004: Primary succession of bryophyte and lichen communities in non-forested Atlantic coastal dunes: the example of the Pointe d'Arcay (France). Nova Hedwigia 78: 453-468.

Kalivodová E., Kubíček F., Bedrna Z., Kalivoda H., Gavlas V., Kollár J., Gajdoš P., Štepanovičová O. \& Wiesbauer H. 2002: Viate piesky Slovenska. [Sand Dunes of Slovakia.] Luka-Press, Bratislava, 60 pp.

Kearns C.A. \& Inouye D.W. 1997: Pollinators, flowering plants and conservation biology. BioScience 47: 297-307.

KLEIN W. 1999: De graafwespen van de Benelux. [The Digger Wasps of the Benelux.] Supplement. Jeugdbondsuitgeverij, Leiden, $37 \mathrm{pp}$.

Kowalchuk G.A., De Souza F.A. \& Van Veen J.A. 2002: Community analysis of arbuscular mycorrhizal fungi associated with Ammophila arenaria in Dutch coastal sand dunes. Molec. Ecol. 11: 571-581.

Lamoot I., Meert C. \& Hoffmann M. 2005: Habitat use of ponies and cattle foraging together in a coastal dune area. Biol. Conserv. 122: 523-536.

LARSSON F.K. 1986: Increased nest density of the digger wasp Bembix rostrata as a response to parasites and predators (Hymenoptera, Sphecidae). Entomol. Gen. 12: 71-75. 
Magura T., Tothmeresz B. \& Molnar T. 2004: Changes in carabid beetle assemblages along an urbanisation gradient in the city of Debrecen, Hungary. Landsc. Ecol. 19: 747-759.

Nielsen E.T. 1945: Moeurs des Bembex. Spol. Zool. M. Hauniensis 7: 1-174.

Peeters T.M.J., Achterberg C. van, Heitmans W.R.B., Klein W.F., Lefeber V., Van Loon A.J., Mabelis A.A., Nieuwenhuysen H., Reemer H., De Rond J., Smit J. \& Velthuis H.H.W. 2004: De wespen en mieren van Nederland (Hymenoptera: Aculeata). (Nederlandse Fauna deel 6). [The Wasps and Ants of the Netherlands (Hymenoptera: Aculeata).] Naturalis en KNNV, 507 pp.

Potts S.G., Vulliamy B., Dafni A., Ne'eman G., Willmer P. 2003: Linking bees and flowers: How do floral communities structure pollinator communities? Ecology 84: 2628-2642.

Provoost S. 2004: Het kustecosysteem. In Provoost S. \& Bonte D. (eds): Levende duinen. Een overzicht van de biodiversiteit in de Vlaamse kuststreek. [The Coastal Ecosystem. In: Living Dunes. An Overview of the Biodiversity along the Flemish Coast.] Mededelingen van het Instituut voor Natuurbehoud, Brussels, pp. 10-45.

Provoost S. \& Bonte D. 2004: Specificiteit van soorten en hun gebruik als bio-indicatoren voor schor en duin. In Provoost $\mathrm{S}$. $\&$ Bonte D. (eds): Levende duinen. Een overzicht van de biodiversiteit in de Vlaamse kuststreek. [Specificity of Species and their Use as Bio-Indicators for Dune and Saltmarsh. In: Living Dunes. An Overview of the Biodiversity along the Flemish Coast.] Mededelingen van het Instituut voor Natuurbehoud, Brussels, pp. 366-415.

Provoost S., Ampe C., Bonte D., Cosyns E. \& Hoffmann M. 2004: Ecology, management and monitoring of dune grasslands in Flanders, Belgium. J. Coastal Conserv. 10: 33-42.
Schöne H. \& Tengö J. 1981: Competition of males, courtship behaviour and chemical communication in the digger wasp Bembix rostrata (Hymenoptera, Sphecidae). Behaviour 77: 44-66.

SChÖNe H., Tengö J., KÜHme D., SchÖNE H., \& Kühme L. 1993: Homing with or without sight of surroundings and sky during displacement in the digger wasp Bembix rostrata (Hymenoptera, Sphecidae). Ethol. Ecol. Evol. 5: 549-552.

SNYDER R.A. \& Boss C.L. 2002: Recovery and stability in barrier island plant communities. J. Coast. Res. 18: 530-536.

Steffan-Dewenter I. \& LeschKe K. 2003: Effects of habitat management on vegetation and above-ground nesting bees and wasps of orchard meadows in Central Europe. Biodiv. Conserv. 12: 1953-1968.

Tengö J., Schöne H. \& Chmurzynski J. 1990: Homing in the digger wasp Bembix rostrata (Hymenoptera, Sphecidae) in relation to sex and age. Ethology 86: 47-56.

Tengö J., Schöne H., Kühme W.D., Schöne H. \& Kühme L. 1996: Nesting cycle and homing in the digger wasp Bembix rostrata (Hymenoptera, Sphecidae). Ethol. Ecol. Evol. 8: 207-211.

van der Meer F. 2002: De angeldragers van Meijendel. [The wasps of Meijendel.] Entomol. Ber. Amsterdam 62: 14-16.

White P.S. \& JeNTSCH A. 2001: The search for generality in studies of disturbance and ecosystem dynamics. Progr. Botany 62: 399-450.

Wiegand T., Dean W., Richard J. \& Milton S. 1997: Simulated plant population response to small-scale disturbances in semiarid shrublands. J. Veget. Sci. 8: 163-176.

ZEGERS T. 2001: Het belang van de duinen voor de Nederlandse Insectenfauna. [The importance of the coastal dune area for the Dutch insect fauna.] Duin 24: 32-35.

Received January 31, 2005; revised and accepted May 5, 2005 